\title{
Some Aspects of South African Cross-Border Insolvency Relief: The Lehane Matter
}

\author{
A Smith*
}

\section{P.E.R}

Pioneer in peer-reviewed, open access, online law publications.

Author

Alastair Smith

Affiliation

University of South Africa, South Africa

Email smithad@unisa.ac.za

Date published

13 December 2016

Editor Prof W Erlank

How to cite this article

Smith A " Some Aspects of South African Cross-Border Insolvency Relief: The Lehane Matter" PER / PELJ 2016(19) - DOI

http://dx.doi.org/10.17159/17273781/2016/v19i0a1221

\section{Copyright}

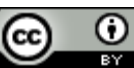

DOI

http://dx.doi.org/10.17159/1727-

3781/2016/v19i0a1221

\section{Abstract}

The Lehane matter wound its way through the Cape Provincial Division of the High Court and reached the Supreme Court of Appeal. Mr Dunne, the Irish debtor who had taken up residence in the United States of America, ran an international web of companies, including Lagoon Beach Hotel, which operated a Cape Town hotel. He filed for chapter 7 bankruptcy in the United States and soon was also bankrupted by the Irish High Court. The Irish official assignee, Lehane, applied to the Cape court for recognition and assistance, and succeeded at every stage of the South African proceedings.

Initially, Steyn $\mathrm{J}$ recognised Lehane as the foreign trustee as though a sequestration order had been granted against Mr Dunne in terms of the Insolvency Act 24 of 1936, thus diverging from the approach taken by the Judicial Committee of the Privy Council in Singularis Holdings Ltd v PricewaterhouseCoopers (Bermuda). Subsequently, Yekiso J's approach to applying the Insolvency Act without derogating from its generality opens up the possibility of applying section 21 of the Insolvency Act to significant effect against Mrs Dunne's South African property. Yet the territorialist restriction in Yekiso J's order that only creditors with causes of action which arose in South Africa were entitled to claim against the insolvent estate excluded many foreign creditors, even those from the Republic of Ireland (Eire).

Of the many issues raised by the Lagoon Beach Hotel company, two chosen for discussion in this case note are the possible application of the automatic stay under section 362 of the United States Bankruptcy Code 1978 to the South African proceedings, and the standing of Lehane because of the litigants' dispute whether Mr Dunne was domiciled in the United States or Ireland.

Yekiso $\mathrm{J}$ and subsequently Leach JA held that the American automatic stay did not govern the South African proceedings. Significantly, the American and the Irish trustees were cooperating with respect to proceedings in Ireland and South Africa that involved Mr Dunne. And Leach JA deftly deferred to the Irish court the decision regarding the application of the American automatic stay and its relevance to the Irish proceedings.

As for the disputed domicile of Mr Dunne, Yekiso $\mathrm{J}$ and Leach JA both considered that Mr Dunne had retained his Irish domicile. Leach JA, though, went on to discuss the assistance that might cautiously be accorded to Lehane if Mr Dunne were domiciled elsewhere than in Ireland. Even then, the relevance of domicile could not be gainsaid. Comparison with the relevant judgments of the Irish courts shows that they also regarded Mr Dunne as having retained his Irish domicile and not having acquired a new domicile of choice in the United States.

In the comments, it is pointed out that trustees appointed in countries other than the insolvent's domicile may still be recognised by South African courts. The insolvent's submitting to the jurisdiction of a court that is not the court of his domicile is discussed; on its facts, the cited authority does not bear out the relevant principle. Further, the possibility of recognising non-domiciliary trustees in exceptional circumstances and for exceptional convenience is explored. The cases cited in support of this principle are shown to yield differing results.

\section{Keywords}

Insolvency law; cross-border insolvency; foreign insolvency no bar to South African proceedings; recognition of foreign non-domiciliary trustee in exceptional circumstances. 


\section{Introduction}

Mr Dunne is the central figure in concurrent bankruptcy proceedings in the United States of America and the Republic of Ireland (Eire). In South Africa the Irish official assignee of Dunne's Irish estate, Mr Lehane, applied to the courts for recognition and assistance. Progressing in stages through the Western Cape Division of the High Court, the Lehane matter arrived in the Supreme Court of Appeal. ${ }^{1}$

After briefly stating the facts, this case comment moves on to Steyn J's provisional order in the Cape in September $2014^{2}$ and places that judge's approach in the context of cross-border insolvency law. Soon the Lehane matter came before Yekiso $\mathrm{J}$ on the return date in October $2014,{ }^{3}$ and features of that judge's order are commented on as regards its scope in relation to section 21 of the Insolvency Act 24 of 1936 and the restriction of the relief to creditors whose causes of action arose wholly in South Africa. Yekiso $\mathrm{J}$ delivered his reserved judgment in January 2015. ${ }^{4}$ In November the Lehane matter reached the Supreme Court of Appeal, ${ }^{5}$ where Leach JA gave the judgment of the court in December. Among the various aspects of Yekiso J's judgment ${ }^{6}$ and Leach JA's, ${ }^{7}$ this case comment focuses on two the automatic stay under American law, and the standing of Lehane to seek relief from the South African courts; both aspects were dealt with convincingly by the courts. The discussion of these aspects is supplemented by references, in footnotes, to the decisions of the Irish High Court $^{8}$ and the Supreme Court of Ireland, ${ }^{9}$ for the light that they throw on aspects of the Lehane matter. After some comments on further points of South African cross-border insolvency law regarding the concepts of submission to the jurisdiction of the foreign court and also the recognition of

* $\quad$ Alastair Smith. BA, LLB (Rhodes), PhD (Edin). Professor, Department of Mercantile Law, School of Law, University of South Africa. E-mail: smithad@unisa.ac.za.

$1 \quad$ Lagoon Beach Hotel v Lehane 20163 SA 143 (SCA) para 8 (hereafter the Lagoon case).

2 Ex parte Lehane (unreported) case number 15678/2014 of 2 September 2014, as described in Lehane $v$ Lagoon Beach Hotel (Pty) Ltd 20154 SA 72 (WCC) para 6 (hereafter the Lehane 2015 case) and the Lagoon case para 6.

$3 \quad$ Lehane v Lagoon Beach Hotel (Pty) Ltd 2014 ZAWCHC 203 (17 October 2014) (hereafter the Lehane 2014 case).

The Lehane 2015 case.

See the Lagoon case.

The Lehane 2015 case.

The Lagoon case.

In the matter of Dunne (a Bankrupt) 2013 IEHC 583 (6 December 2013).

In the matter of Sean Dunne (a Bankrupt) 2015 IESC 42 (15 May 2015). This court is the Irish court of final appeal (Supreme Court of Ireland 2016 http://tinyurl.com/guqp2xo). 
a non-domiciliary trustee in exceptional circumstances, points that serve to highlight the importance of domicile in the South African common law of cross-border insolvency, a conclusion brings this contribution to a close.

\section{The facts of the Lehane matter}

Mr Dunne, a businessman formerly resident in the Republic of Ireland, had moved to the United States. His international web of companies and trusts ${ }^{10}$ included shares in an Irish company, Mavior, owner of all the shares in Lagoon Beach Hotel (Pty) Ltd, which ran a Cape Town hotel. ${ }^{11}$ Mr Dunne had used Mavior to lend funds to Lagoon, and transferred his Lagoon interests to his wife in two contracts and dispositions in 2005 and 2008. In 2013 he sought chapter 7 bankruptcy under the Bankruptcy Code 1978 in the United States, ${ }^{12}$ where Mr Coan was appointed trustee. Soon afterwards, Mr Dunne was also bankrupted by the Irish High Court in Dublin, and Lehane was appointed there.

Lehane heard that Lagoon was about to sell its assets and/or its shares (and its loan account) in South Africa. So he applied to the Cape court for provisional orders to recognise him as Mr Dunne's foreign trustee and to interdict Lagoon from disposing of the proceeds of the sale, pending the outcome of Irish proceedings to impeach the 2005 and 2008 transactions as fraudulent.

\section{The order of Steyn $\mathrm{J}$ in Ex parte Lehane ${ }^{13}$}

In Ex parte Lehane Steyn $\mathrm{J}$ authorised Lehane, once he had furnished security, to administer Mr Dunne's South African property. Lehane as the foreign insolvency representative was accorded all rights under the Insolvency Act 24 of $1936,{ }^{14}$ as though a South African court had issued a

10 The outdated and incomplete Wikipedia page for Sean Dunne gives an idea of his interests and connections: Wikipedia 2016 http://tinyurl.com/zgso89k.

11 The Lagoon case para 2.

12 This step was strategic, not least because honest debtors may expect an American discharge from their debts within one year, sooner than the three years under Irish law (see O'Donovan 2013 http://tinyurl.com/h53c5ls; NAMA Wine Lake 2013 http://tinyurl.com/zq2c76k). Mr Dunne filed for American bankruptcy knowing full well that Irish bankruptcy proceedings against him were imminent (In the matter of Dunne (a Bankrupt) 2013 IEHC 583 (6 December 2013) para 85 per McGovern J in the Irish High Court, in dismissing Dunne's argument to have the Irish bankruptcy proceedings set aside). Although Mr Dunne "was due to exit bankruptcy at the end of [July 2016]", on 11 July 2016 the Irish bankruptcy was extended by the High Court at the request of Lehane, alleging that Mr Dunne was not co-operating (Anon 2016 http://tinyurl.com/jhp4tsy; O'Faolain 2016 http://tinyurl.com/hqekjbg).

13 As described in the Lehane 2015 case para 6 and the Lagoon case para 6.

14 Including those under $\mathrm{s} 64$ on the attendance of meetings by the insolvent and others, $s 65$ on the interrogation of the insolvent and other witnesses, s 66 on the enforcing of summonses and the giving of evidence, section 69 on the trustee's duty to take 
sequestration order on 29 July 2013, the date on which the Irish court appointed him as official assignee.

This important order by Steyn $\mathrm{J}$ should be placed in the context of recent developments in cross-border insolvency law. The order, conferring wide powers upon Lehane as though a local sequestration order applied, typifies the approach of South African courts in applying the Insolvency Act as though it does apply to the facts under a sequestration order, even though a local sequestration order is not issued. This approach was disapproved of by the Judicial Committee of the Privy Council in Singularis Holdings Ltd $v$ PricewaterhouseCoopers (Bermuda). ${ }^{15}$ In that appeal, Lord Collins in particular stated that this approach of applying a statute "as if" it did apply when on its wording it did not apply to the facts amounted to legislating from the bench and thus intruded on the sphere of the legislature. ${ }^{16}$ The approach taken by the South African Appellate Division ${ }^{17}$ was not approved. ${ }^{18}$ Still, the South African approach of applying the Insolvency Act and the legislation on companies remains flexible and assists foreign insolvency representatives, as in the Lehane matter with respect to a natural person. But the approach places South African law at odds with the narrower approach that applies in jurisdictions where Singularis is binding authority. ${ }^{19}$

\section{$4 \quad$ The order by Yekiso $\mathrm{J}$ in Lehane $v$ Lagoon Beach Hotel (Pty) Ltd RO $^{2}$}

The order by Yekiso $\mathrm{J}$ in October 2014 raises questions about the application of certain sections of the Insolvency Act to the facts of the matter.

\subsection{The possible relevance of section 21 of the Insolvency Act to the facts of the Lehane matter}

Yekiso $\mathrm{J}$ applied the Insolvency Act with the necessary changes, ${ }^{21}$ "without derogating from the generality thereof". Specified sections of the Insolvency Act were also listed. The quoted phrase, "without

charge of the estate property, and s 82 on the sale of estate property after the second meeting of creditors.

15 Singularis Holdings Ltd v PricewaterhouseCoopers (Bermuda) 2014 UKPC 36 (10 November 2014), 20152 WLR 971 (hereafter the Singularis case).

16 The Singularis case paras 78-79.

17 Moolman v Builders and Developers (Pty) Ltd (in Provisional Liquidation): Jooste Intervening 19901 SA 954 (A).

18 See the judgments of Lord Sumption JSC and Lord Mance JSC in the Singularis case in paras 24 and 143, respectively.

19 For further discussion of the Singularis case, see Smith 2016 Obiter 167-186.

20 The Lehane 2014 case.

21 The Lehane 2014 case para 3. 
derogating from the generality thereof", may be interpreted as applying the entire Insolvency Act to the facts. Previously, section 21 of the Insolvency Act, governing the property of the solvent spouse in a marriage out of community of property, had been held by Goldstone $\mathrm{J}$ not to be intended to apply extra-territorially. ${ }^{22}$ Statutes are generally assumed not to apply extra-territorially, and they apply in their area of enactment; ${ }^{23}$ comity recognises assignments in bankruptcy as being effective in another country. ${ }^{24}$

The orders of Steyn $\mathrm{J}$ in Ex parte Lehane and Yekiso $\mathrm{J}$ in Lehane $v$ Lagoon Beach Hotel (Pty) Ltd ${ }^{25}$ mention sections 64 to 66, 69 and 82 of the Insolvency Act, and Lehane was accorded rights under these sections. In addition, these sections are to be read together with the phrase quoted above: "without derogating from the generality thereof".

Does this wording of the court order, read as a whole, imply that the court chooses whether section 21 of the Insolvency Act may also apply to the facts of the cross-border insolvency matter? On Goldstone J's reasoning in Viljoen $v$ Venter, ${ }^{26}$ sections 64 to 66,69 and 82 of the Insolvency Act, forming part of this Act, would not apply to the facts of Lehane either; yet Yekiso J's court order in Lehane $v$ Lagoon Beach Hotel (Pty) Lto ${ }^{27}$ applies them expressly to the Lehane matter. If this reasoning about judicial choice applies, the judge hearing the application by the foreign insolvency representative for recognition and assistance seems at liberty to decide whether, if necessary by express reference, some sections of the Insolvency Act will apply to the facts in question. It is conceded that the "rights and duties relating to the election and appointment of a trustee will not apply" in the Lehane matter. ${ }^{28}$ Section 21 of the Insolvency Act, though, is not expressly excluded from applying to the Lehane matter. It has been stated that section 21 of the Insolvency Act is seen as not applicable under the cross-border insolvency law at common law; ${ }^{29}$ and that one difference introduced by the Cross-Border Insolvency Act 42 of 2000 renders section 21 of the

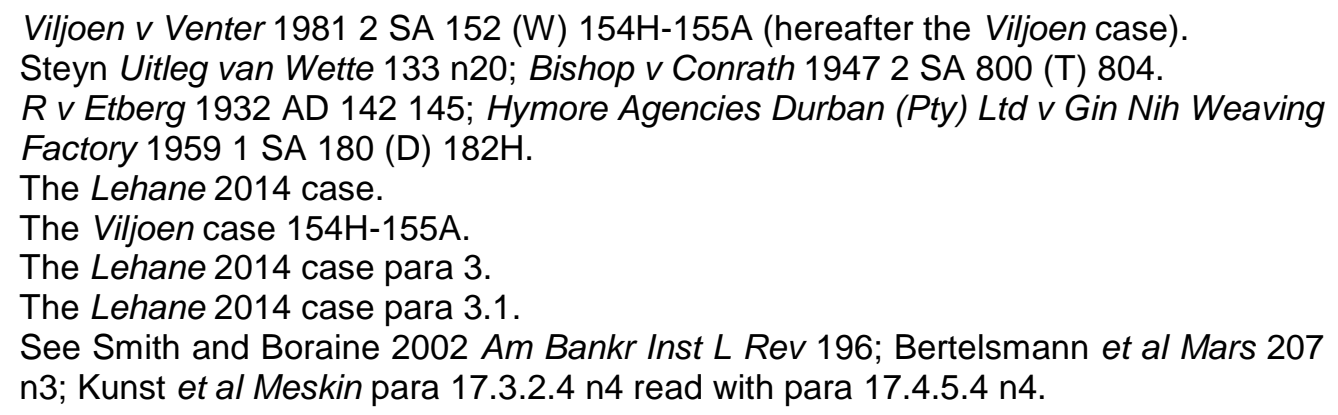


Insolvency Act automatically applicable to foreign main proceedings. ${ }^{30}$ If the reasoning about judicial choice is accepted, though, it seems open to a single judge in another division of the High Court, and to courts of appeal throughout South Africa on whom Goldstone J's ruling in Viljoen $v$ Venter is not binding, to find that section 21 of the Insolvency Act does apply to the facts, if necessary by express mention, in a comprehensively worded order granted to a foreign insolvency practitioner by a South African court under the South African common law of cross-border insolvency.

The Dunnes appear to be still married to each other. On 15 June 2014, Mrs Dunne told a newspaper reporter that she was still married to $\mathrm{Mr}$ Dunne. ${ }^{31}$ The application of section 21 of the Insolvency Act to a local application for recognition would mean that all the South African assets forming part of the solvent spouse's estate would automatically form part of the insolvent spouse's insolvent estate. ${ }^{32}$ The solvent spouse, Mrs Dunne, would then bear the burden of proving to the Irish official assignee, Lehane, that her South African assets should be released on various specified grounds, ${ }^{33}$ one of them being that Mrs Dunne had acquired the property during her marriage to Mr Dunne by a title valid against his creditors. ${ }^{34} \mathrm{~A}$ donation to protect the property against $\mathrm{Mr}$ Dunne's creditors and for his wife's security would be valid had the donation been entered into in good faith. ${ }^{35}$ As Lehane might disregard a simulated or collusive transaction intended to deceive or defraud creditors, ${ }^{36}$ it would then be important to establish, through interrogating the spouses, whether they knew about Mr Dunne's actual or imminent insolvency at the time of the contracts and dispositions in 2005 and $2008 .^{37}$ If Lehane could prove the necessary requirements, he might be able to resist Mrs Dunne's application for the release of her South African assets under section 21(2) of the Insolvency Act. Section 21 of the Insolvency Act might therefore provide a further weapon for Lehane

30 See s 20(1)(d) of the Cross-Border Insolvency Act 42 of 2000. This statute is not yet fully in force, because the Minister has not promulgated the list of states to which the statute applies (s 2(2)-(5) of the Cross-Border Insolvency Act).

31 Quinlan 2014 http://tinyurl.com/zf3uoyx and on 19 February $2016 \mathrm{Mr}$ Aodhan O'Faolain reported that Ms Killilea Dunne, "wife of bankrupt developer Sean Dunne", had not succeeded in her application for her lawyers to be granted permission to crossexamine Mr Coan's lawyer (O'Faolain 2016 http://tinyurl.com/h8d42sj). Section 21(1) of the Insolvency Act 24 of 1936.

Section 21(2) of the Insolvency Act.

Section 21(2)(c) of the Insolvency Act.

Rens v Gutman 20031 SA 93 (C).

Jooste $v$ De Witt 19992 SA 355 (T).

Compare Beddy v Van der Westhuizen 19993 SA 913 (SCA) 916J-917G. 
to have certain transfers set aside because they placed assets beyond the reach of Mr Dunne's creditors. ${ }^{38}$

\subsection{The restriction of the court order to claims by creditors whose whole cause of action arose in South Africa}

The further aspect of Yekiso J's order to comment on is paragraph 3.2, that only creditors whose whole causes of action arose within South Africa could under his court order acquire rights to prove claims. This order manifests the principle of territoriality in the South African cross-border insolvency law. Under this principle, the foreign insolvency representative administers the local assets under the directions of the South African court and administrative officials such as the Master of the High Court. Only any surplus remaining is transferred out of the South African jurisdiction to another jurisdiction where bankruptcy proceedings are running against the debtor. ${ }^{39}$

The wording of paragraph 3.2 of this court order is restrictive, and prevents the filing of any claim whatsoever based on a non-South African cause of action. Creditors with a non-South African cause of action, such as those from the United States or the Republic of Ireland, would seem unable to instruct local South African lawyers to act for them in terms of an appropriate power of attorney. Not even South African creditors of Mr Dunne who had non-South African causes of action against him would be entitled to prove their claims in terms of paragraph 3.2 of the court order.

\section{Comments on the judgments of Yekiso $\mathrm{J}$ in the Lehane 2015 case and Leach JA in the Lagoon case}

Next, this case comment discusses two aspects of the Lehane matter - the American automatic stay supposedly effective automatically throughout the world, and the standing of Lehane to seek relief, including an interdict, from the South African court, bearing in mind that Mr Dunne had previously filed for bankruptcy in America. ${ }^{40}$

38 Compare the Irish impeachment proceedings mentioned in the Lagoon case para 7; also see Kunst et al Meskin para 17.3.2.1 n5.

39 See, for example, Smith 2002 SA Merc LJ 17 para 3; Kunst et al Meskin para 17.1; Bertelsmann et al Mars para 30.2; Sharrock, Van der Linde and Smith Hockly para 26.2. The territorial approach is implicitly supported in Ward v Smit: In re Gurr v Zambia Airways Corporation Ltd 19983 SA 175 (SCA) 179D (hereafter the Ward case); Kunst et al Meskin para $17.1 \mathrm{n} 7$.

40 Compare the Lehane 2015 case paras $42-51$ and 52-57, respectively. 


\subsection{The automatic stay under American law}

Quite some space in the judgments by Yekiso $\mathrm{J}$ and Leach JA was devoted to considering whether the American automatic stay applied to Lehane's South African application and thus prevented the application from being pursued. It is submitted that the key to understanding this aspect of the case was mentioned as early as the first paragraph of Yekiso J's judgment: "His trustee in the US supports these proceedings". ${ }^{41}$ This aspect was identified

41 The Lehane 2015 case. Further background is supplied by the decision of McGovern $\mathrm{J}$ (In the matter of Dunne (a Bankrupt) 2013 IEHC 583 (6 December 2013)) in explaining (para 81) that the US trustee, Coan, himself stated relevant facts that most of Mr Dunne's assets and liabilities were outside the USA, and all his real estate was in Ireland. More than $\$ 14 \mathrm{~m}$ worth of personal assets, and mostly in Ireland, was outside the USA. All his secured and priority claimants were Irish; the vast majority of his unsecured creditors, contract parties, and co-debtors resided in Ireland. Irish law might affect important issues in the bankruptcy. Coan argued for comity to be shown to the Irish bankruptcy proceedings, which were compatible with US law and policy, and that "an Irish bankruptcy case is necessary in this matter for an expeditious, economical and just liquidation of the bankruptcy estate and distribution of its property" (para 83 (original emphasis)). Coan proposed the adoption of a protocol to govern the administration of the bankrupt estate (para 86). A dual bankruptcy was thus approved by McGovern J (paras 75-76), who referred (para 76) to various authorities (Collins et al Dicey, Morris and Collins para 31-077; In re Thulin 19951 WLR 165 (English bankruptcy approved, despite Swedish bankruptcy), including the petitioner's citations (Ex parte Cridland 18143 V \& B 94; Lyall v Jardine, Matheson \& Co 1870 LR 3 PC 318 (see also 18707 Moo PC NS 116, 17 ER 45); Re O'Reardon 1873 LR 9 Ch App 74; Re Artola Hermanos 189024 QBD 640, and Re P MacFadyen \& Co 19081 KB 675). On appeal (In the matter of Sean Dunne (a Bankrupt) 2015 IESC 42 (15 May 2015) per Laffoy J), the Supreme Court of Ireland discussed at length the issue of the jurisdiction of an Irish court to make an adjudication order where a bankruptcy in another state was running (paras 33-64). A distinction had to be drawn between "the jurisdiction to create a concurrent bankruptcy and the effect and consequences of doing so" (para 38). English law permitted a concurrent bankruptcy where a bankruptcy was already running in a state other than the domicile of the debtor (for example, Re Artola Hermanos 189024 QBD 640). In Ireland, the Cridland and O'Reardon cases showed that bankruptcies might co-exist there and in England (In the matter of Sean Dunne (a Bankrupt) 2015 IESC 42 (15 May 2015) paras 44-45). Having considered Irish legislation as not excluding jurisdiction to grant a bankruptcy solely because of a pre-existing foreign bankruptcy (paras 46-52), Lafoy $\mathrm{J}$ then referred to recent UK case law (Rubin v Eurofinance SA 2012 UKSC 46 (24 October 2012), 20131 AC 236) on the principle of modified universalism, which foregrounded a single, unitary bankruptcy. The Supreme Court of Ireland had decided against judicial development rather than legislative development of the relevant cross-border insolvency principles (Re Flightlease (Ireland) Limited (in Voluntary Liquidation) 2012 1 IR 722); the cautious judgment of Lord Sumption JSC in the Singularis case (para 19) was also noted, that modified universality was limited by local law and policy, courts not being free to travel beyond their own statutory and common-law powers. Nevertheless, Lafoy $\mathrm{J}$ held that no legislative or common-law rule in the Republic of Ireland excluded the jurisdiction to bankrupt the debtor simply because of a preexisting foreign bankruptcy (In the matter of Sean Dunne (a Bankrupt) 2015 IESC 42 (15 May 2015) para 58). On the further question of a protocol to be concluded between Coan and Lehane, Lafoy $\mathrm{J}$ held that it was unnecessary and inappropriate at this stage for the Supreme Court of Ireland to discuss the specifics, which might turn out to be 
as the central point by Leach JA in remarking on the co-operation between the American and Irish trustees and the fact that the automatic stay had been lifted in order to allow the Irish proceedings to go ahead. ${ }^{42}$ Similarly, the American trustee gave his approval to the lifting of the automatic stay in respect of the South African application by Lehane. ${ }^{43}$ So it is submitted that it is unnecessary to explore the implications of differences of opinion in the expert evidence led before the Cape court and the Supreme Court of Appeal about the relevance of the American automatic stay to the South African application. The American trustee did not appear before the South African courts in order to oppose the relief that Lehane sought before these courts; and it could be argued that it was not Lagoon's place to raise such an objection on behalf of the American trustee.

As Yekiso $\mathrm{J}$ observed, ${ }^{44}$ in any event section 362 of the American Bankruptcy Code applied to an action regarding a fraudulent transfer and the South African application was not for this form of relief. Still, it is submitted that Leach JA deftly resolved this point by explaining that it was

complicated. The present litigants were the debtor and a major creditor of the debtor, and it was important to note that the American trustee was not before the Supreme Court of Ireland (para 62). It is submitted that the relevance of the UNCITRAL Model Law on Cross-Border Insolvency (1997) and its local adaptation may also be pondered. That item of soft law has been adopted by South Africa (as explained in $\mathrm{fn}$ 30 above) and by the USA (as ch 15 of the US Bankruptcy Code, which is fully in force; see LII 2016 http://tinyurl.com/ja2cpcb; Westbrook 2005 Am Bankr LJ 713), but not by the Republic of Ireland (see UNCITRAL $2016 \mathrm{http}: / /$ tinyurl.com/z9s2zqm). If the USA and the Republic of Ireland were to feature in the Minister's list required by s 2(2)-(5) of the Cross-Border Insolvency Act in South Africa and that statute were thus relevant to facts such as those of the Lehane matter, it is submitted that the connections set out by McGovern J in the High Court (In the matter of Dunne (a Bankrupt) 2013 IEHC 583 (6 December 2013) para 81) would indicate the Republic of Ireland as the centre of the debtor's (Mr Dunne's) main interests and the Irish bankruptcy proceedings therefore as the foreign main proceedings (s 17(2)(a) of the Cross-Border Insolvency Act). On this reasoning, there might, on the facts, be argument over whether the USA might be a place where Dunne as the debtor had an "establishment" ("a place of operations where [he] carries out non-transitory economic activity with human means and goods or services" (s 1(c) of the Cross-Border Insolvency Act)) and the US proceedings were thus foreign non-main proceedings (s 17(2)(b) of the Cross-Border Insolvency Act). The Irish proceedings would thus be privileged as regards the effects of the recognition of foreign main proceedings (s 20 of the Cross-Border Insolvency $A c t)$, including the automatic stay. The relevant provisions on co-operation with foreign courts and foreign representatives (ss 25-27 of the Cross-Border Insolvency Act) might be applied, and there would need to be the appropriate co-ordination of South African and foreign proceedings (ss 28-32 of the Cross-Border Insolvency Act).

42 The Lagoon case paras 21-22.

43 The Lagoon case para 22.

44 The Lehane 2015 case para 50. 
not the South African court's place or responsibility to take judicial notice of the American law or the Irish view on American law. ${ }^{45}$

Part of the reasoning about the possible application of the automatic stay was based on the "... standard position ... that the insolvent estate will fall into the jurisdiction of the first court which grants a sequestration order". 46

Sheldon was cited as authority. ${ }^{47}$ The principle is illustrated by the old Cape case Trustee of Howse, Sons \& Co, Trustees of Howse, Sons \& Co, Jocelyne $v$ Shearer $\&$ Hine,${ }^{48}$ in which the firm had had two domiciles. The winding-up petition was sought and a receiver appointed in London on 25 August. The firm surrendered its Cape estate (comprising only movable property) in the Supreme Court of the Cape of Good Hope on 2 October, and Cape trustees were appointed on 29 October. The London trustee was appointed on 23 November. On 13 December the London Bankruptcy Court requested colonial courts' assistance in recognising the London trustee's appointment. The Cape court set aside the Cape trustees' appointment, and, among other things, declared that the Cape assets vested in the London trustee. ${ }^{49}$

In the Lehane matter Mr Dunne filed for bankruptcy in America on 23 March 2013. Although the Irish bankruptcy proceedings commenced on 12 February, the Irish court granted an order only on 29 July. ${ }^{50}$

Having dealt with the automatic stay, the discussion now turns to the standing of Lehane to apply to the South African court for recognition and assistance.

45 The Lagoon case para 20. It is noted that the Supreme Court of Ireland did not regard the American automatic stay as preventing the institution of the Irish proceedings. It is submitted that such an argument may have been excluded by the express lifting of the automatic stay by Shiff $\mathrm{J}$ in the US proceedings in order to allow the Irish bankruptcy case to proceed (see In the matter of Sean Dunne (a Bankrupt) 2015 IESC 42 (15 May 2015) para 7), as well as by the collaborative attitude of Coan towards the furtherance of the Irish proceedings.

$46 \quad$ The Lagoon case para 18.

47 Sheldon Cross-Border Insolvency paras 28-29.

48 Trustee of Howse, Sons \& Co, Trustees of Howse, Sons \& Co, Jocelyne v Shearer \& Hine 18843 SC 14 22-23 (hereafter the Howse case).

49 Also see Smart Cross-Border Insolvency 343, on the vesting of movable property, with precedents cited from Scotland (Selkrig v Davies 18142 Rose 291, Selkrig v Davies 18142 Dow PC 230, 3 ER 848; Geddes v Mowat 18241 Gl \& J 414; Stewart v Auld 185113 D 1337 1342; Young v Buckel 18642 M 1077; Goetze v Aders 18742 R 150; and Araya $v$ Coghill 1921 SC 462), New Zealand (Cleve $v$ Jacomb 1864 Mac 171) and England (Re Anderson $19111 \mathrm{~KB} 896$ ). 


\subsection{The standing of Lehane to apply to the South African court for recognition and assistance}

\subsubsection{Different approaches to the issue of Mr Dunne's domicile}

Relevant to the issue of Lehane's standing to seek recognition and assistance from the South African courts was the question of Mr Dunne's domicile, ${ }^{51}$ a point disputed because of contradictory statements that he was still domiciled in Ireland rather than, as he averred, currently being domiciled in the United States.

Yekiso $\mathrm{J}$ seemed ill at ease in dealing with the possibility that Mr Dunne might have been domiciled somewhere other than in Ireland. ${ }^{52}$ Still, it is noteworthy that Yekiso $\mathrm{J}^{53}$ mentioned Lehane's argument that "domicile is not an absolute requirement for his recognition", with reliance on Ex parte Palmer: In re Hahn ${ }^{54}$ and included ${ }^{55}$ Berman J's reference in the Palmer case to Innes CJ's cautious finding in Re Estate Morris ${ }^{56}$ about recognising a non-domiciliary trustee in exceptional circumstances. Yet Yekiso $\mathrm{J}$ did not take this line of reasoning any further but simply concluded ${ }^{57}$ that the Irish domicile at the relevant point had been established and confirmed by the Irish High Court. ${ }^{58}$ One infers that Yekiso $\mathrm{J}$ did not consider that the present

51 The Lagoon case para 25-26.

52 The Lehane 2015 case paras 53-57.

53 The Lehane 2015 case para 55.

54 Ex parte Palmer: In re Hahn 1993 3 SA 359 (C) 364I-365B (hereafter the Palmercase).

55 The Lehane 2015 case para 56

56 Re Estate Morris 1907 TS 657666 (hereafter the Morris case).

57 The Lehane 2015 case para 57.

58 Also compare Yekiso J's reference to the relevant finding by McGovern $\mathrm{J}$ in Ireland (the Lehane case 2015 paras 25, 55). In his judgment In the matter of Dunne (a Bankrupt) 2013 IEHC 583 (6 December 2013), McGovern J discussed the facts relevant to Mr Dunne's domicile at some length (paras 31-47), and paid particular regard to Mr Dunne's declaration to a representative of the petitioning bank on 8 November 2010, "My Domicile is Ireland", a statement from which he had not sought to resile or which he had attempted to explain or clarify (para 46). For the purposes of the Irish bankruptcy petition, held the judge, Mr Dunne had thus been domiciled in Ireland within the preceding three years required (see paras 25-30). In the discussion of domicile on appeal, though, Lafoy J held that, strictly speaking, the debtor had to be shown to be domiciled at the date when the bankruptcy petition was presented, a matter of Irish law as the lex fori (In the matter of Sean Dunne (a Bankrupt) 2015 IESC 42 (15 May 2015) para 66). The requirements of proving both the fact of residence and the intention to reside permanently or indefinitely as elements of the acquisition of a new domicile of choice were confirmed (with citation to, among others, In re Sillar, Hurley $v$ Winbush 1956 IR 344 349). Lafoy J acknowledged that, as both parties realised, there was a conflict of evidence on Mr Dunne's domicile at the date of presentation of the petition (para 67), each litigant "implicitly [criticising] the other for not seeking to cross-examine the others' deponent or deponents on the issue of domicile" (para 67). Lafoy $\mathrm{J}$ criticised both litigants for not seeking leave to carry out such cross-examination. Lafoy $\mathrm{J}$ went on to point out one feature of the evidence that in her opinion prevented Mr Dunne from convincing the Irish court that he had acquired 
circumstances fell within the scope of Innes CJ's cautious ruling in the Morris case.

That cautious ruling and the possibility that it created in the Lehane matter were explored by Leach JA in more detail. He mentioned that recognition had been extended to trustees who had not been appointed by the domiciliary court. ${ }^{59}$ The uncertainty over the domicile and the American court's enlistment of the Irish legal system were regarded as constituting the exceptional circumstances. ${ }^{60}$ Leach JA warned that it was "not simply a matter of comity and convenience" 61 which justified the South African courts helping in the present case; the further aspect was that it was "... also intimately bound up with the prima facie case made out against Mr Dunne for his being domiciled in Ireland".

a domicile of choice in the USA: he resided in the USA in terms of an E2 visa. He had not advanced reasons for proving that he had acquired a domicile of choice, since his evidence "raises serious questions whether animus manendi could be or is established" (para 71). Lafoy $\mathrm{J}$ concluded this part of her judgment with the following observations (paras 71-72): "On the evidence, it is not possible to conclude that it was open to the Appellant [Mr Dunne] to form an intention to reside permanently or indefinitely in the United States of America prior to or on 12th February, 2013 which was capable of fulfilment at that time, nor is it possible to conclude that he had, in fact, formed such an intention given that, on his own evidence, he only took steps to acquire the right to remain permanently or indefinitely in the United States of America in reaction to Mr. Hurson's affidavit sworn on 28th August, 2013 which disclosed his legal status. ... Apart from that point, a large number of factual matters are relied on by the Petitioner [Ulster Bank Ireland Limited] in support of its contention that the Appellant has not discharged the onus of proving that he has acquired a domicile of choice in the United States of America. Some of those factual matters were also outlined by the trial judge [McGovern J] in his judgment. Many of those matters demonstrate a continuing connection between the Appellant and this jurisdiction such as to lead to the conclusion that he has not established that he has abandoned his domicile of origin permanently and indefinitely." Again, it is submitted that these findings by McGovern at trial and Lafoy $\mathrm{J}$ on appeal show that the findings by Yekiso $\mathrm{J}$ and Leach $\mathrm{JA}$ that $\mathrm{Mr}$ Dunne had retained his Irish domicile were correct. Sinead O'Carroll wrote the following about the decision of the South African Supreme Court of Appeal: "The complicated ruling ... focused on where Dunne's official place of residence is. Muddled by claims he lived in the US, Geneva and Ireland (at the same time), the court decided that the property developer's domicile must for legal purposes be Ireland" (O'Carroll $2015 \mathrm{http}: / /$ tinyurl.com/h6wfuvo). It is submitted that the Supreme Court of Appeal, on the evidence, was not muddled over Mr Dunne's domicile, but correct in finding that he had failed to prove that he had given up his domicile in Ireland and acquired a new American domicile of choice.

59 The Lagoon case para 31.

60 The Lagoon case para 32.

61 The Lagoon case para 32. 
5.2.2 The significance of domicile in the recognition of foreign insolvency representatives

5.2.2.1 The general principle regarding recognition of the domiciliary trustee

The significance of domicile is now discussed. The general principle concerns the recognition of the domiciliary trustee. In the Palmer case ${ }^{62}$ Berman $\mathrm{J}$ ruled that the debtor needed to be domiciled where the court granted the order, otherwise South African courts would not recognise the trustee appointed by that court. For this principle, Berman $\mathrm{J}$ relied on the ruling in the Morris case ${ }^{63}$ that

... all our decisions hitherto have been based upon the fact that the sequestration order which we recognised and enforced was made at the domicile of the insolvent. It is only such an order which could, without the recognition of other Courts, have any operation outside the jurisdiction of the Court which granted it.

Berman $\mathrm{J}$ followed up this point by saying that the general principle concerning the recognition of foreign trustees was trite law. ${ }^{64}$

O'Brien argued ${ }^{65}$ that the Morris quotation was not authority for Berman J's ruling in Palmer on this point. Instead, the quotation concerned the orders that might automatically apply beyond the jurisdiction of the domiciliary court, without needing to be formally recognised. As O'Brien adds, it "does not follow that only orders made by the court of the insolvent's domicile may be recognised".66 First, it is submitted that foreign insolvency representatives, not foreign sequestration or liquidation proceedings, are recognised ${ }^{67}$ Further, it is submitted that the possibility of recognising other foreign trustees is implied by the fact that in the Palmer case Berman $\mathrm{J}$ mentioned two possible exceptions to the general principle of recognising the domiciliary trustee. This submission would be consistent with O'Brien's observation.

62 The Palmer case 3611.

63 The Morris case 666.

64 The Palmer case 365C-D, citing Farlam AJ in Smit v Abrahams 19923 SA 158 (C) 180C-D.

65 O'Brien "Transnational Aspects" 17.

66 O'Brien "Transnational Aspects" 17.

67 See O'Brien "Transnational Aspects" 14-15, discussing Ex parte Getliffe: In re Dominion Reefs Ltd 19654 SA 75 (T); Re African Farms Ltd 1906 TS 373; and Ex parte Robinson's Trustee 1910 TPD 25. 
5.2.2.2 The first exception: submission of the non-domiciliary trustee to the local court's jurisdiction

The first possible exception acknowledged by Berman $\mathrm{J}$ in the Palmer case was that recognition might be accorded if the insolvent had sought his sequestration in a country where he was not domiciled. Then his trustee one infers, from that non-domiciliary jurisdiction - "... might ... be able to obtain recognition in the country of the insolvent's domicile on the basis of the doctrine of submission". ${ }^{68}$

This possibility was not discussed in detail in the Lehane matter, where Mr Dunne submitted himself to the jurisdiction of the American bankruptcy court by seeking bankruptcy under chapter 7 of the Bankruptcy Code. The reason that this possibility was not discussed may be that it was not relevant to the South African facts. The basis on which this possible exception might apply would be that the United States was not Mr Dunne's domicile at the time of the Irish bankruptcy proceedings, and that, instead, Ireland was that domicile, and the American trustee was seeking recognition in the Irish court. Mr Dunne was not domiciled at the Cape. So in applying to the South African court for recognition and assistance, Lehane was not applying, on the basis of the doctrine of submission, for recognition in the country of the insolvent's domicile.

And how far does the authority relied on - the Richards case - in fact illustrate the principle for which it was cited in support of the first exception mentioned in the Palmer case? Doveton resided and was domiciled and had all his assets in the Cape Colony. He was not subject to the jurisdiction of the High Court of Griqualand. He gave his agent in Kimberley an ordinary general power of attorney. Process was served on that agent. The High Court of Griqualand gave judgment against Doveton and in July granted a compulsory sequestration order against his estate and appointed Richards as the trustee. A copy of the Griqualand sequestration was not sent to the Supreme Court of the Cape of Good Hope until December.

Meanwhile, in September the High Court of Griqualand confirmed Richards as the trustee of the Griqualand estate. In addition, in September Doveton, who knew of the Griqualand sequestration order, had applied to surrender his estate in the Cape Colony. The Cape court was not informed of the Griqualand sequestration or Richards's appointment in that jurisdiction. In October the Cape court confirmed the appointment of the Cape trustees of Doveton's estate.

68 Berman J in the Palmer case 364H-I cited Richards $v$ Doveton's Trustees 18843 SC 123126 (hereafter the Richards case). 
At no (prior) stage had the Cape court known of the Griqualand sequestration. Richards maintained that he did not know of the Cape proceedings, although they had been advertised. He applied to have the appointment of Doveton's Cape trustees set aside. The Griqualand power of attorney was not placed in evidence before the Cape court.

In a short judgment, De Villiers CJ held that Richards had to prove that these Cape orders had been mistakenly granted and that the Cape court was obliged to give effect to the Griqualand court's order. Richards argued that Doveton had granted the agent in Kimberley the power of attorney with the general power of representation. De Villiers CJ held ${ }^{69}$ that Richards's argument would be sound if clearly the power of attorney was broad enough to entitle the agent to submit to the Griqualand court's jurisdiction. It had to be assumed that the relevant power of attorney was the standard one. The power of attorney would even be taken to confer on the general agent the power to accept service on the insolvent's behalf. Still, this power of attorney would not be broad enough for Richards's purposes, because

... a bare authority to accept service means no more than an authority to accept service within the jurisdiction to which the person giving the authority is subject. ${ }^{70}$

De Villiers CJ then distinguished the Richards case from the Howse case, where the insolvent firm had had two domiciles. In the Howse case,

... it was held that upon the insolvency of the firm, and the appointment of a trustee in one domicile, the estate in the other domicile was vested in such trustee. ${ }^{71}$

Yet in the Richards case, Doveton "never was amenable to the insolvency jurisdiction of the High Court" of Griqualand. ${ }^{72}$ The Griqualand appointment of Richards did not prevent the Cape court from appointing local trustees to manage the Cape estate that Doveton had surrendered. So Richards's application failed.

Despite the conferring of the general power of attorney on the Kimberley agent, who received process there, it is noticeable that the Cape court, when belatedly informed of the pre-existing Griqualand court's sequestration order, did not recognise it. So the Richards case, on its facts, is not authority for the principle that a debtor may submit to the jurisdiction of the foreign court and then the trustee appointed to the relevant insolvent estate may rely on the resulting sequestration order as a basis sufficient in

\footnotetext{
The Richards case 126.

The Richards case 126.

The Richards case 126.

The Richards case 126.
} 
a local court exercising jurisdiction over the debtor by virtue of his domicile and his property both being within the jurisdictional area of that local court.

From dealing with the first exception to the general principle, the discussion moves on to the second exception to the general principle regarding the recognition of foreign insolvency representatives.

5.2.2.3 The second exception: recognition of the non-domiciliary trustee in exceptional cases and for exceptional convenience

The second possible exception to the general principle that Berman $\mathrm{J}$ discussed in the Palmer case ${ }^{73}$ was permitted by Innes CJ's cautious ruling in the Morris case. This second possibility was that the insolvent's domiciliary court might recognise a non-domiciliary trustee in exceptional cases and for exceptional convenience. Berman $\mathrm{J}$ mentioned three cases in this regard. These are now considered in turn.

First, in Herman $v$ Tebb, ${ }^{74}$ the estate of the debtor, Tebb, had been sequestrated in the Transvaal in 1911 and soon afterwards he came to live in the Cape, where he had subsequently been domiciled. Several years later he had been rehabilitated in the Transvaal.

His immovable property was governed by Cape law. No Cape movable property had been acquired while he had been domiciled in the Transvaal, and so Cape law applied to all his property. Had sequestration occurred in the Cape, all his Cape property would vest in a Cape trustee. The Transvaal sequestration order, as regards its effect on property that Tebb had acquired in a domicile other than the Transvaal, should be seen as being issued by a non-domiciliary court, and thus could be effective regarding "property within the jurisdiction of the Court which pronounced it", the Transvaal. ${ }^{75}$ The Cape property did not vest in the Transvaal trustee.

Louwrens $\mathrm{J}$ held that he retained discretion to recognise the Transvaal trustee. Among other things, such recognition would lead to the debtor's losing a Cape liquor licence and prevent him from managing his Cape estate. The Transvaal trustee was not the domiciliary trustee, nor was he vested with any of Tebb's assets. The Transvaal law would apply to immovable property situated in the Transvaal if Tebb was still domiciled in the Transvaal. The Cape movables could not be dealt with or taken to the Transvaal unless the Cape court allowed this move. The Cape court could grant the order, subject to conditions; but that order, Louwrens $\mathrm{J}$ considered,

\footnotetext{
The Palmer case $364 \mathrm{I}-365 \mathrm{C}$.

Herman v Tebb 1929 CPD 65 (hereafter the Herman case).

The Herman case 72, Louwrens J citing the Morris case.
} 
should not be granted if the administration of the estate and the handling of the assets would conflict with the law of the debtor's domicile and the place where his property was situated, or the policy of the legal system of that place. ${ }^{76}$ Such an extensive order should not be granted where the trustee was not vested with the assets, the debtor was solvent, and his Transvaal creditors could sue him for their debts by means of other remedies. The only two Transvaal creditors' claims had prescribed under Cape law as the lex fori. Louwrens $\mathrm{J}$ thus refused to recognise the Transvaal trustee.

It is acknowledged that in broad terms Louwrens $\mathrm{J}$ did consider whether the Cape court could recognise the trustee. He decided against doing so. The principle that the application for recognition could be entertained can be deduced from the circumstances of the case; but, as far as the afteracquired movable property in the Cape was concerned, one infers that those circumstances were not so extraordinary as to render it appropriate for the Cape court to recognise the Transvaal trustee, who had been appointed so many years previously.

The second case cited by Berman $\mathrm{J}$ in the Palmer case was the Rhodesian case of MTD (Mangula) Ltd v Frost and Power: Ex parte Power. ${ }^{77}$ There the South African court had appointed a curator bonis to manage the debtor's affairs. There was no proof whether the debtor (who it seems was solvent but old and unable to manage his affairs) had been domiciled in South Africa or somewhere else when the Rhodesian application for recognition was heard. This point was disputed. ${ }^{78}$ The South African curator bonis still applied to the Rhodesian court regarding the Rhodesian estate, and was recognised. This Rhodesian decision in the MTD (Mangula) case illustrates the possibility that the local court may recognise the foreign representative who may not be proved to be the domiciliary trustee, provided that he still takes care to apply for recognition to the local court and does not make the mistake of attempting to deal with the local assets without such recognition, or even of being slow to make the application for recognition as were the Zambian liquidators in the Ward case. The Rhodesian decision in the MTD (Mangula) case illustrates a generous approach to recognising a foreign representative. It is also noticeable that the court in the MTD (Mangula) case intended its order of recognition to apply to property whether movable or immovable.

\footnotetext{
76 Compare Bertelsmann et al Mars para 30.8 n34.

77 M T D (Mangula) Ltd v Frost and Power: Ex parte Power 19662 SA 713 (R) (hereafter the MTD (Mangula) case).

78 The MTD (Mangula) case $716 \mathrm{H}$.
} 
The third case cited by Berman $\mathrm{J}$ in the Palmer case - Ex parte Singer: In re Insolvent Estate Skeen ${ }^{79}$ - also has some interesting features. The debtor had previously resided in the Transvaal, moved to Natal, and then moved again to the Cape and died there. The Transvaal trustee applied to the Natal court for recognition so that he might deal with the debtor's movable property and immovable property in Natal. In the absence of proof of the debtor's Transvaal domicile, Beaumont $\mathrm{J}$ held that the debtor had been domiciled in Natal when he died. ${ }^{80}$

The Natal court recognised the Transvaal trustee as being able to deal with the Natal movable property, ${ }^{81}$ a decision not challenged on appeal. Again, when the Singer case is compared with the Herman case, it is clear that it was the non-domiciliary trustee from the Transvaal who was seeking recognition from the Natal court. So to that extent the decision bears out the principle that the non-domiciliary trustee may still be recognised by the court of the debtor's domicile, as regards movable property. But the outcome for the Transvaal trustee in the Singer case was different from the outcome for the Transvaal trustee in the Herman case. Although both the debtors were held to have acquired new domiciles in Herman and Singer, it is submitted that the point of distinction was the lapse of a considerable period of time in Herman.

Further, in the Singer case the Natal court also had to decide the position regarding the debtor's immovable property situated in Natal. In this respect, the appeal court in the Singer case (Bale CJ, Dove-Wilson J and Broome J) reached a decision different from the decision that had been reached regarding the Natal movable property. It was acknowledged that the Natal court exercised jurisdiction over this immovable property. As regards whether the Natal court should in comity recognise the Transvaal trustee, the court followed the decision of the Transvaal Supreme Court in Ex parte Stegmann. ${ }^{82}$ The appeal court in the Singer case declined to set aside the decision reached by Beaumont $\mathrm{J}$ in the exercise of his discretion. The appeal court gave various reasons (including the finding that Skeen had been domiciled in Natal and not the Transvaal) why it would be convenient for the immovable property to be dealt with in Natal. ${ }^{83}$ Accordingly, this part of the judgment and the order of the court of appeal state the general principle regarding the treatment of immovable property. It is submitted that

79 Ex parte Singer: In re Insolvent Estate Skeen 190526 NLR 536 (hereafter the Singer case).

$80 \quad$ The Singer case 547.

81 The Singer case 538.

82 Ex parte Stegmann 1902 TS 40. See the Singer case 545-547.

83 The Singer case 547. 
this part of the judgment in the Skeen case does not fall within the exception acknowledged by the cautious language of Innes CJ in the Morris case.

In the Palmer case, ${ }^{84}$ Berman $\mathrm{J}$ held that comity and convenience were not a separate ground for a South African court to recognise a foreign trustee "regardless of any consideration given to the" domicile of the insolvent. This factor explains why Leach JA referred to Lehane's prima facie case establishing Mr Dunne's Irish domicile. ${ }^{85}$ However, as the Rhodesian case of MTD (Mangula) and the old Natal case of Singershow (at least in relation to the movable property in the Singer case), recognition may be accorded if the non-domiciliary foreign representative does apply to the local court for such recognition. The lack of proof of the required domicile may not be fatal to the success of the application. But it appears that the application by the non-domiciliary trustee for recognition must be prompt, otherwise this trustee faces the obstacle of another rule of cross-border insolvency law, that property acquired after the insolvent has acquired a new domicile of choice does not vest in the trustee appointed in his previous domicile. ${ }^{86}$ If this conclusion is correct, then domicile is seen to continue to play a decisive role in the decision whether to recognise and assist a foreign insolvency representative.

\section{Conclusion}

This case comment has discussed some aspects of the relief that South African courts are prepared to grant to foreign representatives. These parties seek the required recognition so as to be allowed to deal with South African assets. The terms of the relief granted to the foreign insolvency representative in the Lehane matter are wide, opening up the possible application of section 21 of the Insolvency Act to the facts, an outcome that would greatly assist a foreign trustee such as Lehane if he sought to convince the South African court that the insolvent spouse's transfer of property to the solvent spouse was an invalid donation at the time that it was made.

At the same time, the territorial nature of the South African order in Lehane is observed by its restricting the claims of creditors to those whose whole

84 The Palmer case 365C.

85 The Lagoon case para 32.

86 The Herman case. This principle regarding property acquired in a new domicile of choice may also be seen in operation in the Morris case, where the debtor had creditors and immovable property in Rhodesia but had moved to the Transvaal and acquired a domicile and movable property in that state; and it was held that although a non-domiciliary trustee could be recognised, the court in its discretion should on the balance of convenience not recognise and assist the Rhodesian trustee in the circumstances of the case. 
cause of action arose in South Africa. This paragraph of the order rules out the possibility of cross-filing by a creditor with a foreign cause of action who wishes to claim for the amount, or the balance, of a claim made in a foreign jurisdiction. This cross-filing would not be allowed even to a creditor from the debtor's domicile, whether the United States or the Republic of Ireland, in the Lehane matter. It follows that this paragraph of the Cape court order would also rule out the claim of a South African creditor whose whole cause of action had not arisen in South Africa.

The finding that the automatic stay conferred by the relevant provision of the Bankruptcy Code in the United States did not apply in South Africa was correct. Yet the significance of the question was seen to wane when on appeal it was pointed out that the American and the Irish trustees were collaborating. The American trustee's approval of the South African proceedings constituted a further lifting of the American worldwide automatic stay, even supposing that it did apply to the type of proceedings undertaken by Lehane in South Africa.

The question of Mr Dunne's domicile was dealt with on the basis that this was in Ireland rather than America. This was the finding of Yekiso J, who did not explore the question of whether recognition might still be accorded to Lehane if Mr Dunne were domiciled in America. Instead, this aspect was discussed more thoroughly by Leach JA in the light of the conflicting statements over the domicile of Mr Dunne, although the judge similarly concluded that on the facts Mr Dunne had retained his Irish domicile and not acquired a new domicile in America. Even as regards the recognition of a non-domiciliary trustee, the question of the domicile of the debtor is seen to be an important factor, as the discussion of the cases with respect to the two exceptions mentioned in the Palmer case shows.

\section{Bibliography}

\section{Literature}

Bertelsmann et al Mars

Bertelsmann E et al Mars: The Law of Insolvency in South Africa ${ }^{\text {th }}$ ed (Juta Cape Town 2008)

Collins et al Dicey, Morris and Collins

Collins L et al Dicey, Morris and Collins: The Conflict of Laws $14^{\text {th }}$ ed (Sweet and Maxwell London 2006)

Kunst et al Meskin

Kunst JA et al Meskin: Insolvency Law and Its Operation in Winding-Up electronic version (LexisNexis Durban 1990-) 
O'Brien "Transnational Aspects"

O'Brien P "Transnational Aspects in South African Insolvency Law" Unpublished contribution delivered at the Rand Afrikaans University Research Unit for Banking Law Reform of South African Insolvency Law Conference (28 August 1995 Johannesburg)

Sharrock, Van der Linde and Smith Hockly

Sharrock R, Van der Linde K and Smith A Hockly's Insolvency Law $9^{\text {th }}$ ed (Juta Cape Town 2008)

Sheldon Cross-Border Insolvency

Sheldon R (ed) Cross-Border Insolvency $4^{\text {th }}$ ed (Bloomsbury London 2015)

Smart Cross-Border Insolvency

Smart P St J Cross-Border Insolvency $2^{\text {nd }}$ ed (Butterworths London 1998)

Smith 2002 SA Merc LJ

Smith A "Some Aspects of Comity and the Protection of Local Creditors in Cross-Border Insolvency Law: South Africa and the United States Compared" 2002 SA Merc LJ 17-30

Smith 2016 Obiter

Smith A "Assisting Foreign Insolvency Practitioners in Cross-Border Insolvency: Some Foreign Insights into South African Law: Singularis Holdings Ltd $v$ PricewaterhouseCoopers (Bermuda) [2014] UKPC 36 (10 November 2014), [2015] 2 WLR 971: cases" 2016 Obiter 167-186

Smith and Boraine 2002 Am Bankr Inst L Rev

Smith A and Boraine A "Crossing Borders into South African Insolvency Law: From the Roman-Dutch Jurists to the UNCITRAL Model Law" 2002 Am Bankr Inst L Rev 135-215

Steyn Uitleg van Wette

Steyn LC Die Uitleg van Wette $4^{\text {th }}$ ed (Juta Cape Town 1974)

Westbrook 2005 Am Bankr LJ

Westbrook JL "Chapter 15 at Last" 2005 Am Bankr LJ 713-728

\section{Case law}

\section{South Africa}

Beddy $v$ Van der Westhuizen 19993 SA 913 (SCA)

Bishop v Conrath 19472 SA 800 (T)

Ex parte Getliffe: In re Dominion Reefs Ltd 19654 SA 75 (T) 
Ex parte Lehane (unreported) case number 15678/2014 of 2 September 2014

Ex parte Palmer: In re Hahn 19933 SA 359 (C)

Ex parte Robinson's Trustee 1910 TPD 25

Ex parte Singer: In re Insolvent Estate Skeen 190526 NLR 536

Ex parte Stegmann 1902 TS 40

Herman v Tebb 1929 CPD 65

Hymore Agencies Durban (Pty) Ltd v Gin Nih Weaving Factory 19591 SA $180(\mathrm{~N})$

Jooste $v$ De Witt 19992 SA 355 (T)

Lagoon Beach Hotel v Lehane 20163 SA 143 (SCA)

Lehane v Lagoon Beach Hotel (Pty) Ltd 2014 ZAWCHC 203 (17 October 2014)

Lehane v Lagoon Beach Hotel (Pty) Ltd 20154 SA 72 (WCC)

Moolman v Builders and Developers (Pty) Ltd (in Provisional Liquidation): Joostelntervening 19901 SA 954 (A)

M T D (Mangula) Ltd v Frost and Power: Ex parte Power 19662 SA $713(\mathrm{R})$ $R v$ Etberg 1932 AD 142

Re African Farms Ltd 1906 TS 373

Re Estate Morris 1907 TS 657

Rens v Gutman 20031 SA 93 (C)

Richards v Doveton's Trustees 18843 SC 123

Smit v Abrahams 19923 SA 158 (C)

Trustee of Howse, Sons \& Co, Trustees of Howse, Sons \& Co, Jocelyne $v$ Shearer \& Hine 18843 SC 14

Viljoen $v$ Venter 19812 SA 152 (W)

Ward v Smit: In re Gurr v Zambia Airways Corporation Ltd 19983 SA 175 (SCA)

\section{United Kingdom and other jurisdictions}

Araya $v$ Coghill 1921 SC 462

Cleve v Jacomb 1864 Mac 171

Ex parte Cridland 18143 V \& B 94 
Geddes v Mowat $18241 \mathrm{Gl} \& \mathrm{~J} 414$

Goetze v Aders 18742 R 150

In re Thulin 19951 WLR 165

In re Sillar, Hurley $v$ Winbush 1956 IR 344

In the matter of Dunne (a Bankrupt) 2013 IEHC 583 (6 December 2013)

In the matter of Sean Dunne (a Bankrupt) 2015 IESC 42 (15 May 2015)

Lyall $v$ Jardine, Matheson \& Co 1870 LR 3 PC 318 (see also 18707 Moo PC NS 116, 17 ER 45)

Re Anderson 19111 KB 896

Re Artola Hermanos 189024 QBD 640

Re Flightlease (Ireland) Limited (in Voluntary Liquidation) 20121 IR 722

Re O'Reardon 1873 LR 9 Ch App 74

Re P MacFadyen \& Co 19081 KB 675

Rubin v Eurofinance SA 2012 UKSC 46 (24 October 2012), 20131 AC 236

Selkrig v Davies 18142 Rose 291, Selkrig v Davies 18142 Dow PC 230, 3 ER 848

Singularis Holdings Ltd v PricewaterhouseCoopers (Bermuda) 2014 UKPC 36 (10 November 2014), 20152 WLR 971

Stewart v Auld 185113 D 1337

Young v Buckel 18642 M 1077

\section{Legislation}

South Africa

Cross-Border Insolvency Act 42 of 2000

Insolvency Act 24 of 1936

\section{United States}

Bankruptcy Code, 1978

International law instruments

UNCITRAL Model Law on Cross-Border Insolvency (1997)

\section{Internet sources}

Anon 2016 http://tinyurl.com/jhp4tsy 
Anon 2016 High Court Extends Sean Dunne Bankruptcy http://tinyurl.com/jhp4tsy accessed 11 July 2016

LII 2016 http://tinyurl.com/ja2cpcb

Legal Information Institute 201611 US Code Chapter 15 - Ancillary and Other Cross-Border Cases http://tinyurl.com/ja2cpcb accessed 11 July 2016

NAMA Wine Lake 2013 http://tinyurl.com/zq2c76k

NAMA Wine Lake 2013 Exclusive! Sean Dunne Files for Bankruptcy in US on Good Friday http://tinyurl.com/zq2c76k accessed 7 July 2016

O'Carroll 2015 http://tinyurl.com/h6wfuvo

O'Carroll S 2015 Seán Dunne's Wife Won't Profit from the Sale of Luxury Hote/ http://tinyurl.com/h6wfuvo accessed 11 July 2016

O'Donovan 2013 http://tinyurl.com/h53c5ls

O'Donovan D 2013 What Irish 'Bankruptcy' Means for Bust Developer Sean Dunne http://tinyurl.com/h53c5ls accessed 7 July 2016

O'Faolain 2016 http://tinyurl.com/h8d42sj

O'Faolain A 2016 Gayle Killilea Dunne Fails in Move to Quiz US Lawyer http://tinyurl.com/h8d42sj accessed 7 July 2016

O'Faolain 2016 http://tinyurl.com/hqekjbg

O'Faolain A 2016 High Court Grants Extension to Sean Dunne's Bankruptcy http://tinyurl.com/hqekjbg accessed 19 July 2016

Quinlan 2014 http://tinyurl.com/zf3uoyx

Quinlan R 2014 Divorce Not on Cards for Sean Dunne and Gayle Killilea http://tinyurl.com/zf3uoyx accessed on 12 July 2016

Supreme Court of Ireland $2016 \mathrm{http}: / /$ tinyurl.com/guqp2xo

Supreme Court of Ireland 2016 About the Supreme Court http://tinyurl.com/guqp2xo accessed 7 July 2016

UNCITRAL 2016 http://tinyurl.com/z9s2zqm

United Nations Commission on International Trade Law 2016 Status: UNCITRAL Model Law on Cross-Border Insolvency (1997) http://tinyurl.com/z9s2zqm accessed 11 July 2016

Wikipedia 2016 http://tinyurl.com/zgso89k

Wikipedia 2016 Seán Dunne (Businessman) http://tinyurl.com/zgso89k accessed 11 July 2016

\section{List of Abbreviations}

Am Bankr LJ

American Bankruptcy Law Journal 
Am Bankr Inst L Rev

LII

SA Merc LJ

UNCITRAL
American Bankruptcy Institute Law Review Legal Information Institute

South African Mercantile Law Journal

United Nations Commission on International

Trade Law 